\title{
SOSIALISASI DAN PELATIHAN TEKNIS PEMBUATAN LUBANG RESAPAN BIOPORI SEBAGAI SOLUSI PENCEGAHAN DAN PENANGANAN BANJIR DI KOTA TANJUNGPINANG
}

\author{
M. Yusuf MF $^{1^{*}}$, UlfaHanum ${ }^{1}$ \\ ${ }^{1}$ Poltekkes Kemenkes Tanjungpinang, Kota Tanjungpinang \\ *Email: muh.yusuf.mf@gmail.com
}

Diterbitkan:13 Agustus 2019

\begin{abstract}
The problem of flooding that hits parts of Indonesia nowadays is mostly caused by human activities, such as a lack of concern for protecting the environment, making construction structures or building facilities without taking into account of open land areas, and disposing of garbage in water drainage streams. Many applicable methods are used to prevent and control floods in urban areas, one of which is by making biopore infiltration holes. Biopore is holes in the soil that are formed due to the activity of organisms, where its function is to increase water absorption, to reduce the risk of flooding, and to preserve the environment. The advantages of making biopore infiltration holes are practical, economical, and environmentally friendly. The aim of this community service activity is to conduct educational counseling and technical training by making biopore infiltration holes to the inhabitants in Tanjungpinang City, in order to prevent and overcome floods, especially during the rainy season. The methodology of this community service activity consists of 4 stages, namely survey and observation, socialization and technical training, practice of making biopore infiltration holes, and evaluation of activities. Based on the results of the activities being carried out, participation and collaboration with the inhabitants went well and cooperatively, the application of biopore infiltration holes being made was 15 spots along the rainwater inundation pathways, and the results of monitoring and evaluation of 15 biopore infiltration holes were functioning properly to be absorbing medias of rainwater overflow so that it can prevent flooding around residential areas. Thus, this community service activity having been carried out contributed and shared benefits to the inhabitants in Tanjungpinang City, especially for transferring knowledge and skill by making biopore infiltration holes to prevent and overcome flooding independently and sustainably.
\end{abstract}

Keywords: Socialization, technical training, biopore infiltration hole

\begin{abstract}
ABSTRAK
Permasalahan banjir yang melanda sebagian wilayah di Indonesia dewasa ini, lebih banyak disebabkan oleh ulah manusia sendiri, seperti kurangnya kepedulian untuk menjaga lingkungan, membangun gedung atau fasilitas bangunan tanpa memperhitungkan area lahan terbuka, dan membuang sampah di aliran drainase air. Banyak cara dan metode aplikatif yang dilakukan dalam mencegah dan mengendalikan banjir di kawasan perkotaan, salah satunya dengan membuat lubang resapan biopori. Biopori adalah lubang-lubang di tanah yang terbentuk karena aktivitas organisme di dalamnya, yang berfungsi untuk meningkatkan daya resapan air, mengurangi risiko banjir, dan melestarikan lingkungan. Keuntungan dari pembuatan lubang resapan biopori adalah praktis, ekonomis, dan ramah lingkungan. Tujuan dari kegiatan pengabdian masyarakat ini adalah melakukan sosialisasi dan pelatihan teknis pembuatan lubang resapan biopori kepada masyarakat di Kota Tanjungpinang, guna mencegah dan menanggulangi banjir, khususnya ketika musim penghujan. Adapun Metodologi kegiatan yang dilakukan mencakup 4 tahapan, yaitu survei dan observasi, sosialisasi dan pelatihan teknis, praktik pembuatan lubang resapan biopori, dan evaluasi kegiatan. Berdasarkan hasil kegiatan yang telah dilakukan, parstisipasi dan kerjasama dengan masyarakat berjalan dengan baik dan kooperatif, aplikasi lubang resapan biopori yang dibuat berjumlah 15 titik di sepanjang jalur genangan air hujan, dan hasil monitoring serta evaluasi 15 titik lubang resapan biopori telah berfungsi dengan
\end{abstract}


baik untuk menjadi media penyerap luapan air hujan sehingga dapat mencegah banjir di sekitar kawasan perumahan. Dengan demikian, kegiatan pengabdian masyarakat yang telah dilakukan memberikan kontribusi dan manfaat positif bagi masyarakat di Kota Tanjungpinang, khususnya dalam transfer pengetahuan dan keahlian dalam membuat lubang resapan biopori guna mencegah dan menanggulangi banjir secara mandiri dan berkelanjutan.

Kata kunci: Sosialisasi, pelatihan teknis, lubang resapan biopori

\section{PENDAHULUAN}

Pemanfaatan sumber daya alam berupa tanah dan air sebagai salah satu modal dasar pembangunan nasional, harus dilaksanakan sebaik-baiknya berdasarkan azas kelestarian, keserasian, dan azas pemanfaatan yang optimal, yang dapat memberikan manfaat ekonomi, ekologi, dan sosial secara seimbang. Penggunaan pemanfaatan tanah dan lahan yang tidak sesuai dengan kaidah-kaidah konservasi dan melampaui kemampuan daya dukungnya, akan menyebabkan terjadinya lahan kritis. Selain itu, perilaku masyarakat yang belum mendukung pelestarian tanah dan lingkungan menyebabkan terjadinya bencana alam banjir pada musim penghujan. Untuk menghindari hal tersebut, maka perlu dilakukan upaya pelestarian lahan kritis, dan pengembangan fungsi biopori pada lahan kritis guna memulihkan kesuburan tanah, melindungi tata air, dan kelestarian daya dukung lingkungan. Permasalahan banjir telah menjadi permasalahan lingkungan di kota-kota dengan tingkat perkembangan pertumbuhan penduduk dan perluasan kebutuhan perumahan tempat tinggal, di Tanjungpinang misalnya, meski sudah ada upaya pelebaran di beberapa titik, namun Tanjungpinang belum aman dari masalah banjir. Berdasarkan daftar Dinas Pekerjaan Umum, Penataan Ruang dan Pertanahan bidang Sumber Daya Air (SDA) Pemerintah Provinsi Kepulauan Riau, masih tercatat sekitar 72 titik di Tanjungpinang yang rawan banjir.

Cukup tingginya curah hujan di Tanjungpinang dan minimnya kesadaran masyarakat terhadap pelestarian lingkungan telah menyebabkan terjadinya penurunan fungsi lingkungan, termasuk kurangnya partisipasi dan kontribusi masyarakat dalam menjaga dan melestarikan lingkungan sekitar. Dengan demikian, dalam rangka pemanfaatan sumber daya alam baik berupa tanah dan air guna mencegah terjadinya banjir dan kerusakan lingkungan, maka perlu direncanakan dan dikelola secara tepat melalui suatu sistem pengelolaan Lubang Resapan Biopori (LRB). Biopori (biopore) merupakan ruangan atau pori dalam tanah yang dibentuk oleh makhluk hidup, seperti fauna tanah dan akar tanaman. Bentuk biopori menyerupai liang (terowongan kecil) dan bercabang-cabang yang sangat efektif untuk menyalurkan air dan udara di dalam tanah. Liang pada biopori terbentuk oleh adanya pertumbuhan dan perkembangan akar tanaman di dalam tanah serta meningkatnya aktivitas fauna tanah, seperti cacing tanah, rayap, dan semut yang menggali liang di dalam tanah.

Salah satu upaya pokok dalam pengelolaan LRB adalah pengaturan keseimbangan pada lingkungan yang kurang daerah peresapan. Aplikasi biopori sangat efektif dan solutif diimplementasikan di perumahan-perumahan yang memiliki kondisi tanah yang kritis dan kurang efektifnya sistem drainase yang berjalan. Berdasarkan hal tersebut, maka kegiatan sosialisasi dan pelatihan teknis pembuatan lubang resapan biopori ini dilakukan di kawasan padat hunian dengan tingkat daya resap air yang rendah dan intensitas banjir yang sering terjadi ketika musim hujan. Salah satu kawasan yang menjadi titik rawan banjir di Tanjungpinang yakni kawasan perumahan sekitar Kampung Kolam, Tanjungpinang Barat. Pelaksanaan kegiatan pengabdian masyarakat ini merupakan salah satu langkah efektif dan solutif untuk pencegahan dan penanganan banjir serta menjaga kelestarian lingkungan sekitar, mengingat belum banyaknya kegiatan partisipasi masyarakat untuk mengatasi permasalahan yang terjadi, sehingga harapannya dapat meningkatkan kesadaran dan kepedulian masyarakat perumahan kawasan sekitar Kampung Kolam secara mandiri dan berkelanjutan dalam menjaga dan melestarikan lingkungan sekitar perumahan, sekaligus menumbuhkan jiwa partisipatif dan menjadi pelopor gerakan cinta lingkungan melalui aplikasi lubang resapan biopori sebagai solusi dalam mencegah, menangani, dan menanggulangi banjir yang masih menjadi isu lingkungan krusial di Tanjungpinang, khususnya pada lokasi titik banjir yang selalu menjadi langganan banjir ketika datangnya musim penghujan, dalam hal ini di kawasan sekitar Kampung Kolam, Batu Hitam, Tanjungpinang Barat. 


\section{METODE}

Metode pelaksanaan kegiatan pengabdian masyarakat ini berupa kegiatan sosialisasi (komunikasi dan penyuluhan) dan bimbingan teknis pembuatan lubang resapan biopori, dengan khalayak sasaran dalam kegiatan ini adalah masyarakat di lingkungan sekitar kawasan perumahan Kampung Kolam, Tanjungpinang Barat, dimana pemilihan lokasi ini berdasarkan hasil observasi terhadap situasi dan kondisi lokasi yang banyak terdapat genangan air hujan hingga menyebabkan banjir dan belum adanya inisiatif warga untukmengatasi masalah terserbut. Adapun realisasi tahapan pelaksanaan kegiatan pengabdian masyarakat ini meliputi 4 tahapan, yakni (1) Survei, observasi, dan pengamatan lokasi kegiatan; (2) Pelaksanaan kegiatan sosialisasi dan pelatihan teknis pembuatan lubang resapan biopori; (3) Pelaksanaan kegiatan pembuatan dan pemasangan media pipa lubang resapan biiopori; dan (4) Pelaksanaan monitoring dan evaluasi kegiatan. Adapun tahapan pelaksanaan kegiatan pengabdian masyarakat dan deskripsi materi kegiatan pengabdian masyarakat dijabarkan di bawah ini.

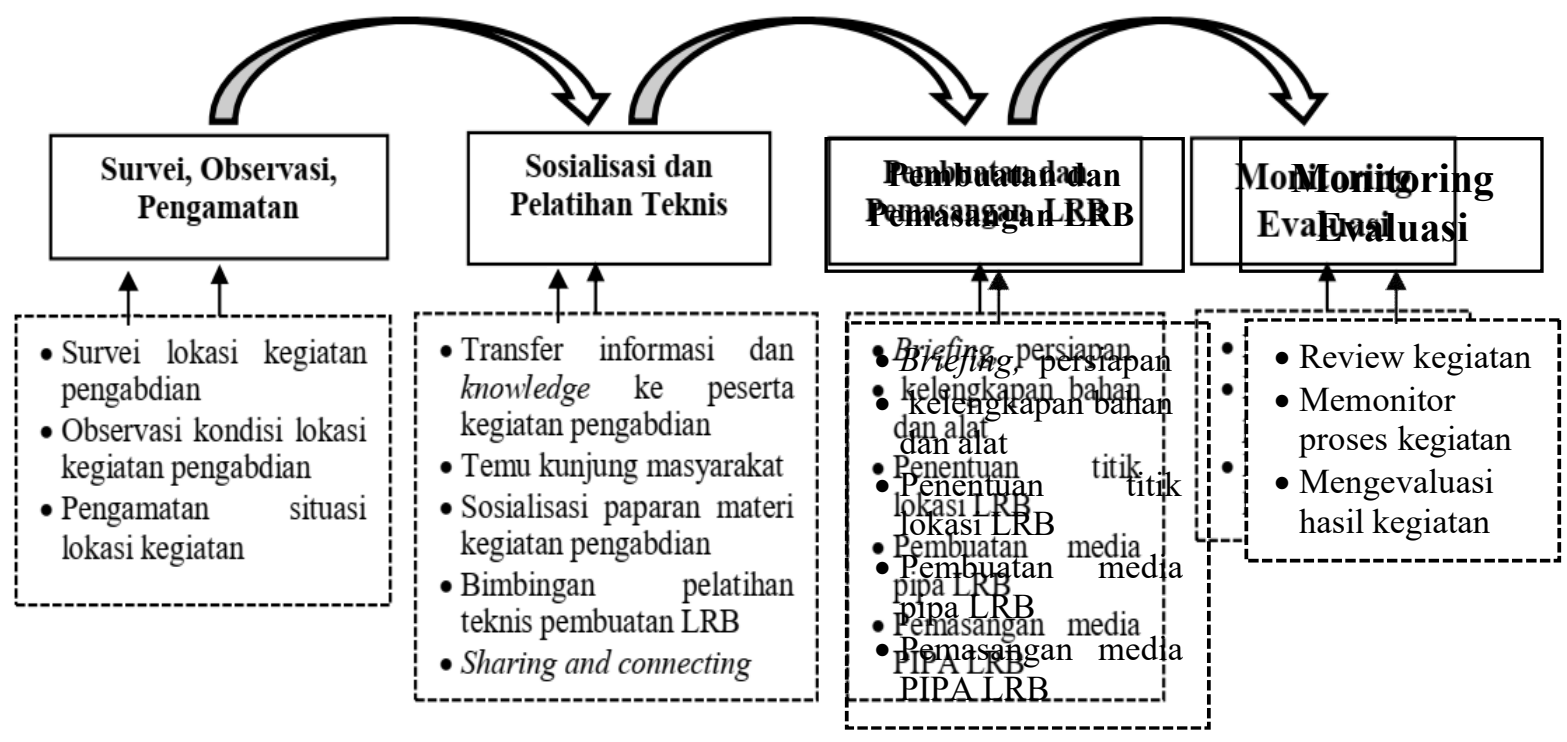

Gambar 1. Tahapan Pelaksanaan Kegiatan

Tabel 1. Materi Kegiatan

\begin{tabular}{clll}
\hline No. & Materi Pengabdian & \multicolumn{1}{c}{ Content/Outline } & \multicolumn{1}{c}{ Keterangan } \\
\hline 1 & Apa Itu Biopori? & Konsep dasar, Definisi, & Pemateri : Tim Pelaksana \\
& & Ruang Lingkup, Dimensi, & Sasaran : Masyarakat Kampung Kolam \\
& & Karakteristik, Peranan, & Metode : Ceramah dan Tanya Jawab \\
& & Urgensi, dan & Waktu : Sabtu (08.00-11.00) \\
& & Implementasi & Alat : Papan edukasi, handout, laptop \\
\hline 2 & Fungsi dan Manfaat & Konsep dasar, Definisi, & Pemateri : Tim Pelaksana \\
& Lubang Resapan & Ruang Lingkup, Dimensi, & Sasaran : Masyarakat Kampung Kolam \\
& Biopori & Karakteristik, Peranan, & Metode : Ceramah dan Tanya Jawab \\
& & Urgensi, dan & Waktu : Sabtu (08.00-11.00) \\
& & Implementasi & Alat : Papan edukasi, handout, laptop \\
\hline 3 & Cara Membuat Lubang & Konsep dasar, Definisi, & Pemateri : Tim Pelaksana \\
& Resapan Biopori & Ruang Lingkup, Dimensi, & Sasaran : Masyarakat Kampung Kolam \\
& & Peranan, Urgensi, & Metode : Ceramah dan simulasi \\
& & Karakteristik, dan & Waktu : Sabtu (08.00-11.00) \\
& Implementasi & Alat : Bahan dan alat biopori \\
\hline 4 & Praktik Teknis & Partisipasi langsung & Tutor dan pembimbing : Tim Pelaksana \\
& Langsung Pembuatan & pengajaran pembuatan & Sasaran : Masyarakat Kampung Kolam \\
& Lubang Resapan & lubang resapan biopori & Metode : Bimbingan teknis dan praktik \\
& Biopori & & Waktu : Sabtu \& Minggu (08.00-11.00) \\
& & & Alat : Bahan dan alat biopori \\
\hline
\end{tabular}




\section{HASIL DAN PEMBAHASAN}

Secara keseluruhan pelaksanaan kegiatan pengabdian masyarakat yang telah dilakukan berjalan dengan baik dan lancar. Partisipasi, kerjasama, dan bantuan dari pihak-pihak yang terlibat, baik internal maupun eksternal, dilakukan dengan baik dan kooperatif. Hasil pelaksanaan kegiatan pengabdian masyarakat ini disusun dan disesuaikan dengan tahapan pelaksanaan kegiatan yang telah dilakukan, yakni mencakup : (a) Kegiatan survei, observasi, dan pengamatan lokasi pengabdian; (b) Kegiatan sosialisasi dan pelatihan teknis pembuatan lubang resapan biopori; (c) Kegiatan pembuatan dan pemasangan media lubang resapan biopori; dan (d) Kegiatan monitoring dan evaluasi hasil kegiatan. Selanjutnya pembahasan dalam kegiatan pengabdian masyarakat ini diuraikan ke dalam 4 klasifikasi kajian, yakni (1) Karakteristik lokasi kegiatan; (2) Karakteristik peserta kegiatan; (3) Proses pelaksanaan kegiatan; dan (4) Hambatan dan tantangan pelaksanaan kegiatan.

Pada tahapan survei dan observasi lokasi kegiatan, scope lokasi yang dipilih untuk menjadi objek pelaksanaan kegiatan yakni di kawasan Perumahan Kampung Kolam, Batu Hitam, Tanjungpinang Barat, dengan beberapa pertimbangan alasan penting sebagai berikut :

1) Kawasan Kampung Kolam merupakan salah satu kawasan zona paling rawan banjir yang ada di Kota Tanjungpinang

2) Banyak terdapat titik-titik genangan air hujan di lingkungan perumahan Kampung Kolam, bahkan sering mengalami banjir jika hujan besar

3) Belum adanya inisiatif warga setempat untuk mengatasi masalah genangan air hujan

4) Belum adanya kegiatan pelibatan warga setempat unrtuk membuat lubang resapan biopori

5) Tesedianya forum berkumpul warga (assembly point) di lingkungan perumahan warga, sehingga sangat mendukung dalam pelaksanaan kegiatan sosialisasi di lokasi tersebut.

6) Adanya antusiasme dan sambutan hangat dari ketua RT dan warga setempat untuk melakukan program gerakan cinta lingkungan.

Tahap kedua dalam pelaksanaan kegiatan pengabdian masyarakat ini adalah kegiatan sosialisasi dan bimbingan pelatihan teknis pembuatan lubang resapan biopori di lingkungan kawasan perumahan Kampung Kolam. Kegiatan sosialisasi dan bimbingan teknis ini dilakukan dengan melibatkan pihak internal (tim pelaksana dan pembantu lapangan) dan pihak eksternal (peserta dan warga Batu Hitam), dimana pada kegiatan kedua ini tim pelaksana memberikan informasi dan transfer pengetahuan mengenai definisi lubang resapan biopori, fungsi dan manfaat lubang resapan biopori, dan cara membuat lubang resapan biopori. Kegiatan sosialisasi dan bimbingan teknis ini berjalan dengan baik dan kooperatif. Partisipasi dan kerjasama antara tim pelaksana dan peserta kegiatan terjalin harmonis dan pada tahapan tahapan kedua ini juga dilakukan penentuan titik atau spot pemasangan media pipa lubang resapan biopori. Berikut dikumentasi gambar yang memperlihatkan proses pelaksanaan kegiatan tahapan kedua dan pemasangan titik pipa lubang resapan biopori di sepanjang jalan utama perumahan Kampung Kolam.

Tahapan ketiga dalam kegiatan pengabdian masyarakat yang dilakukan yakni pembuatan dan pemasangan media lubang resapan biopori di titik-titik yang sudah ditentukan dan ditandai sebelumnya. Kegiatan tahapan ketiga ini dilakukan dengan melibatkan tim pelaksana dan warga peserta kegiatan. Pelaksanaan kegiatan pembuatan dan pemasangan media lubang resapan biopori ini terdiri dari beberapa step/langkah kegiatan, yakni (1) Persiapan media pipa paralon; (2) Penggalian lubang tanah sedalam $80 \mathrm{~cm}$; (3) Pemasangan media pipa ke dalam lubang; (4) Penambahan sampah organik ke dalam lubang pipa; (5) Penutupan lubang pipa; dan (6) Penimbunan kembali lubang biopori. Adapun dokumentasi kegiatan tahapan ketiga yang telah dilakukan dapat dilihat di bawah ini.
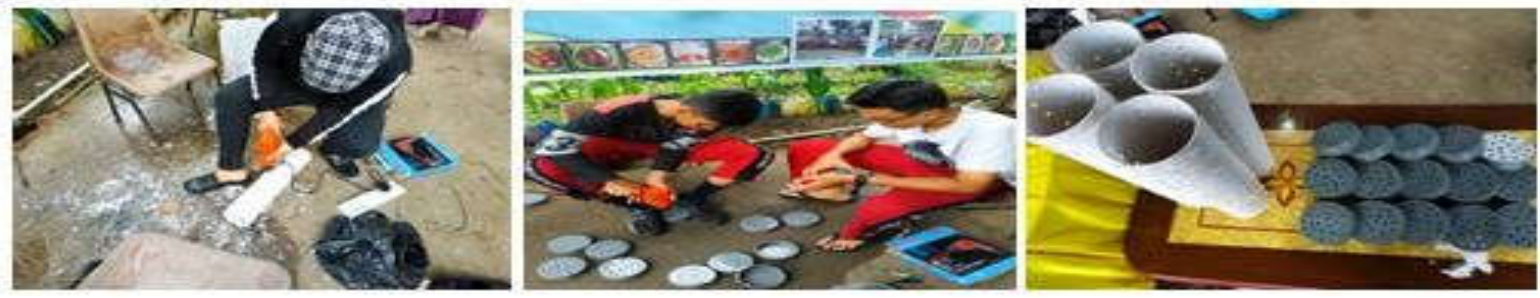

Gambar 2. Foto Persiapan media paralon biopori 

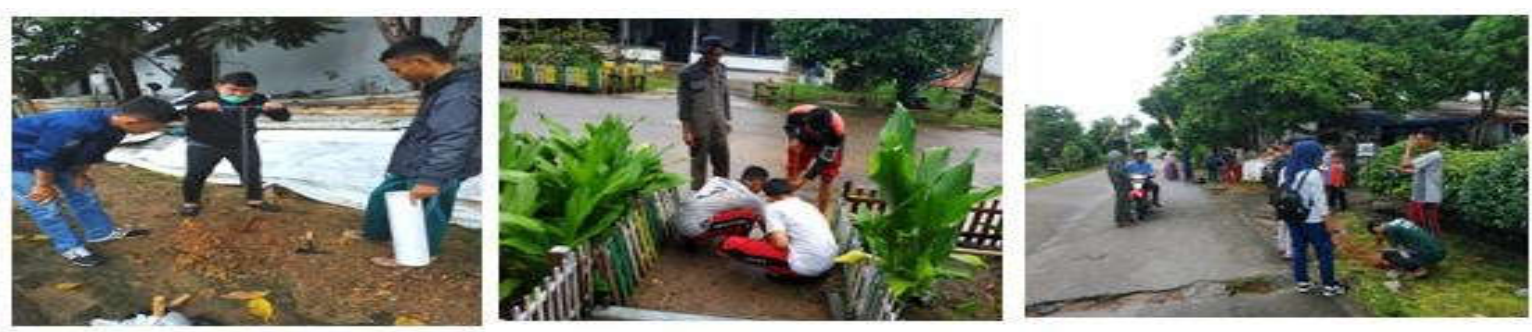

Gambar 3. Proses penggalian lubang resapan biopori
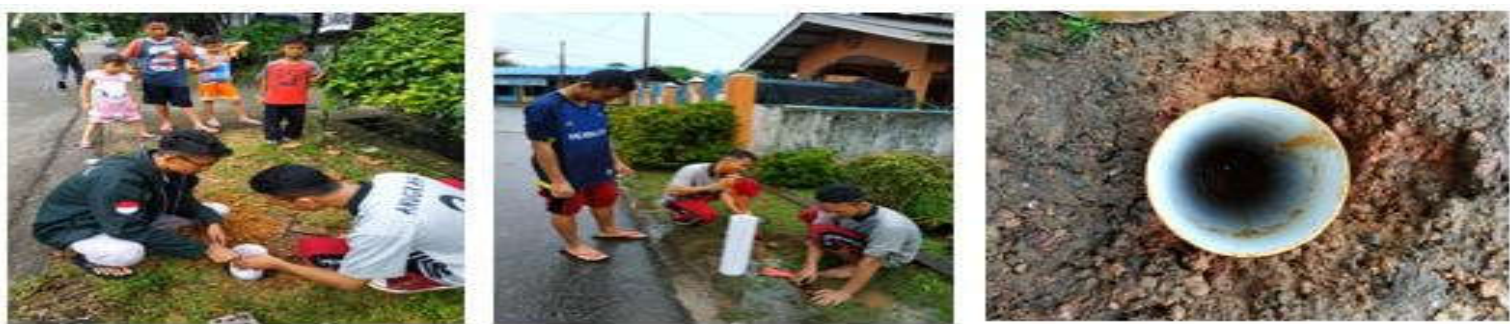

Gambar 4. Pemasangan media pipa biopori
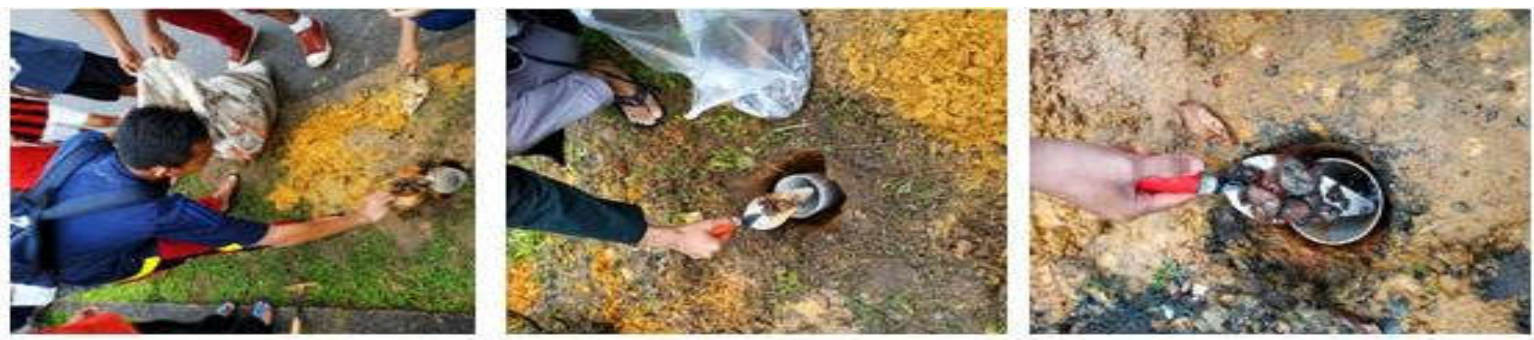

Gambar 5. Proses pengisian sampah organik pada pipa biopori
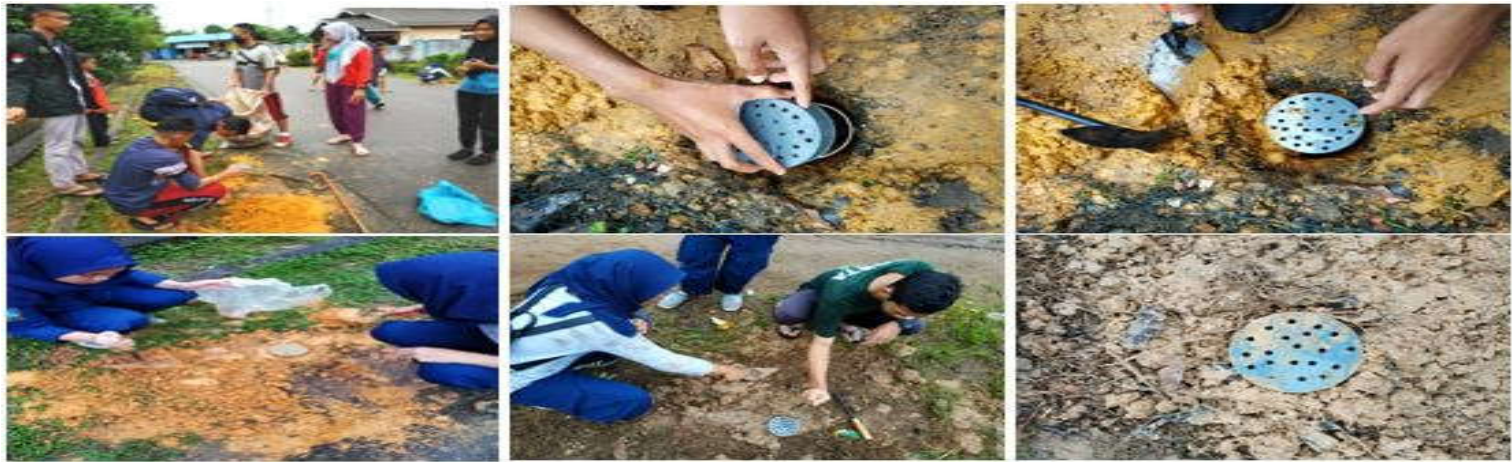

Gambar 6. Proses penutupan dan penimbunan pipa lubang resapan biopori 
Tahapan kegiatan keempat dalam pengabdian masyarakat ini adalah monitoring dan evaluasi proses dan hasil pelaksanaan kegiatan. Monitoring dan evaluasi dilakukan oleh tim rmonev pengabdian masyarakat yang telah ditunjuk untuk melakukan pengamatan dan penilaian terhadap kegiatan yang dilakukan. Sementara monitoring dan evaluasi yang dilakukan oleh tim pelaksana pengabdian dimaksudkan untuk memantau kelancaran dan keberhasilan kegiatan yang telah disusun dan dilakukan. Dokumentasi kegiatan monitoring dan evaluasi disajikan di bawah ini.

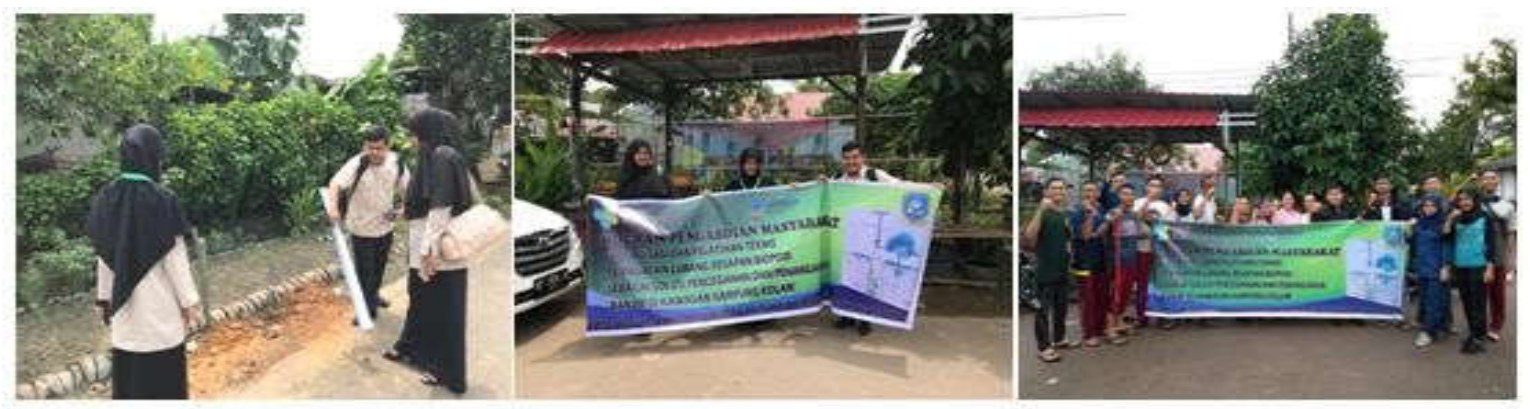

Gambar 7. Monitoring dan Evaluasi Kegiatan

Berdasarkan hasil pelaksanaan kegiatan pengabdian masyarakat yang telah dilakukan di Kawasan Perumahan Kampung Kolam, Kota Tanjungpinang, dapat dikatakan berjalan dengan baik dan lancar. Adanya koordinasi, kerjasama, dan pelibatan masyarakat Perumahan Kampung Kolam telah menjadikan kegiatan pengabdian masyarakat ini berjalan dengan sukses dan telah memberikan sumbangsih serta manfaat yang positif bagi warga setempat, khususnya dalam transfer pengetahuan dan keterampilan membuat lubang resapan biopori di lingkungan perumahan guna mencegah dan menangani masalah banjir. Karakteristik peserta kegiatan dalam pengabdian masyarakat ini adalah warga Perumahan Batu Hitam , Kampung Kolam, Tanjungpinang Barat. Antusiasme dan sambutan hangat dari peserta kegiatan sangat baik dan peserta juga mendukung adanya kegiatan pengabdian masyarakat di lingkungan perumahan mereka mengingat kawasan perumahan tersebut masih sering terjadi banjir jika hujan besar dan belum adanya inisiatif warga untuk membuat lubang resapan biopori sebagai solusi untuk menaangani genangan air hujan.

Proses pelaksanaan kegiatan pengabdian masyarakat ini pada umumnya berjalan dengan baik dan lancar. Komunikasi, koordinasi, dan kerjasama dengan pihak-pihak terlibat berlangsung dengan sukses dan kooperatif. Pada kegiatan survei, observasi, dan pengamatan lokasi kegiatan, dalam hal ini di Perumahan Kampung Kolam telah memenuhi kriteria dan kesesuaian atas isu kegiatan yang diangkat, sehingga penentuan lokasi kegiatan yang dipilih sudah tepat dan sesuai dengan ruang lingkupnya. Sementara pada kegiatan sosialisasi dan bimbingan teknis pembuatan lubang resapan biopori yang telah dilakukan juga berjalan dengan baik dan lancar. Partisipasi dan pelibatan masyarakat berjalan dengan kooperatif dan adanya peningkatan pengetahuan dan keterampilan peserta selama proses kegiatan berlangsung. Proses inti dari pelaksanaan kegiatan pengabdian masyarakat ini adalah pembuatan dan pemasangan media pipa lubang resapan biopori ke 15 titik genangan air. Pada umumnya proses kegiatan ini berjalan dengan sukses dan pipa-pipa yang ditanam sebagai media penyerap air hujan berfungsi sebagaimana mestinya. Hal ini telah dipantau juga pada tahapan kegiatan monitoring dan evaluasi selama proses pelaksanaan dan setelah pelaksanaan kegiatan. Pelaksanaan kegiatan pengabdian masyarakat ini tentunya terdapat beberapa hambatan dan tantangan di dalam proses perencanaan, penyusunan, dan pelaksanaannya. Beberapa hambatan dan tantangan yang ditemui selama pelaksanaan kegiatan masih bisa diselesaikan dengan baik pada saat pelaksanaan berlangsung. Berikut ini adalah beberapa hambatan dan tantangan yang muncul selama pelaksanaan kegiatan, diantaranya sebagai berikut: 1) Alat bor biopori yang tidak tersedia, sehingga harus didesain dan dibuat terlebih dahulu dan memerlukan waktu yang cukup lama; 2) Karakteristik tanah di lokasi kegiatan yang banyak terdapat batuan dan adanya jalur penanaman pipa air serta jaringan kabel tanah di sepanjang jalur titik-titik lubang resapan biopori; dan 3) Cuaca yang kurang mendukung pada saat pelaksanaan kegiatan.

\section{SIMPULAN}

Cukup tingginya curah hujan di Kota Tanjungpinang dan minimnya kesadaran masyarakat terhadap pelestarian lingkungan telah menyebabkan terjadinya penurunan fungsi lingkungan, seperti terjadinya banjir di berbagai kawasan di Tanjungpinang, termasuk lingkungan kawasan perumahan Kampung Kolam. Kegiatan pengabdian masyarakat ini secara umum berjalan dengan baik dan lancar, dimana kegiatan ini dilakukan di lokasi Perumahan Batu Hitam, Kampung Kolam 
Tanjungpinang Barat, dengan melibatkan pihak internal (tim pelaksana 2 orang dan 10 orang pembantu lapangan) dan pihak eksternal (peserta kegiatan dan warga Perumahan Kampung Kolam). Kegiatan ini terdiri dari empat tahapan, meliputi (a) Kegiatan survei, observasi, dan pengamatan lokasi kegiatan; (b) Kegiatan sosialisasi dan pelatihan teknis pembuatan lubang resapan biopori; (c) Kegiatan pembuatan dan pemasangan media lubang resapan biopori; dan (d) Kegiatan monitoring dan evaluasi hasil kegiatan. Hasil pelaksanan kegiatan pengabdian masyarakat ini berupa 15 lubang resapan biopori yang telah ditanam di lingkungan Perumahan Kampung Kolam dan telah memberikan kontribusi serta manfaat positif sebagai media penjerat air sehingga dapat mencegah dan menananggulangi banjir yang sering terjadi di lingkungan perumahan peserta kegiatan. Rekomendasi yang perlu dikembangkan untuk keberlanjutan ke depannya, diantaranya Perlunya keberlanjutan kegiatan program sejenis lainnya di lokasi kegiatan, seperti kegiatan rutin bersih kompleks perumahan, urban farming, holistikasi pembuatan kompos, dan penataan taman perumahan, dan lain sebagainya.

\section{DAFTAR PUSTAKA}

[1] Anonim. (2018). Biopori: Teknologi Tepat Guna Ramah Lingkungan. $h$ ttp://www.biopori.com. [Diakses Agustus 2018].

[2] Arifin S, dkk,. (2012). Menjaga Kelestarian Lingkungan Dengan Biopori. Jakarta: Prosiding The 4th International Conference on Indonesian Studies: "Unity, Diversity and Future".

[3] Brata K.R dan Anne Nelistya. (2011). Lubang Resapan Biopori. Depok : Swadaya.

[4] Campbell, NA., Reece, J.B., Mitchell, L.G.. 2002. Biologi. Penerbit Erlangga, Jakarta

[5] Hilwatulisan. (2011). Lubang Resapan Biopori (LRB) Pengertian dan Cara Membuatnya di Lingkungan Kita. Jurnal Teknik Kimia, Politeknik Negeri Sriwijaya, eprints polsri, Sumatera Selatan.

[6] Kamir R Brata. (2006). Teknologi Biopori. IPB Press, Bogor.

[7] Karuniastuti, Nurhenu. (2015). Teknologi Biopori untuk Mengurangi Banjir dan Tumpukan Sampah Organik. Forum Teknologi, Vol. 04 No.2.

[8] Maryati, dkk,. (2010). Lubang Resapan Biopori (LRB) Teknologi Teknologi Tepat Guna Untuk Mengatasi Banjir dan Sampah serta Menjaga Kelestarian Air Bawah. Yogyakarta: Tim PPM Biopori UNY.

[9] Pusat Pendidikan Lingkungan Hidup. 2013. Manfaat Lubang Biopori. http://pplhselo.or.id/berita/manfaat-lubang-biopori.html. [Diakses Agustus 2018].

[10] Redaksi Tanjungpinang Pos. (2017). Tanjungpinang Masih Rawan Banjir. http://tanjungpinangpos.id/tanjungpinang-masih-rawan-banjir/. [Diakses Agustus 2018].

[11] Suaib. (2017). Kampung Kolam Dilanda Banjir. http://koranpeduli.co.id/?p=10669. [Diakses Agustus 2018].

[12] Tim Biopori IPB. (2017). Atasi Banjir dengan Teknologi Lubang Resapan Biopori. http://www.biopori.com/news_atasibanjir.php. [Diakses Agusttus 2018]. 